pubescence except that the third has a broadly triangular black central patch, the apex of which is directed hindwards. Apex rufous. Second segment at sides and ventrally strongly punctured, dorsally the surface cannot be seen because of the pubescence.

Hab.--Gordon Town, Jamaica. (Dr. Cargill.) Communicated by $\mathrm{Mr}$. L. O. Howard. Type in U. S. Nat. Museum. A very beautiful and distinct species.

\section{Chrysididae.}

Holopyga semirufa, n. sp. - Length about or slightly over $3 \mathrm{~mm}$; head and thorax bright green, occiput and metathorax deep purple. Antennae very dark brown, the scape green. Pro- and meso-thorax shining slightly reddish brassy in some lights. Metathorax with a very little green mid- dorsally. Wings clear, nervures dark brown. Abdomen moderately shining, entirely rufous. Legs rufous, anterior and middle femora and tibiae darker, anterior femora green except the end.

Whole insect strongly punctured, the punctures finer on the abdomen. Third segment of abdomen entire. Claw with two teeth within. Marginal cell open at apex; no discoidal cells, the outline of the second is very faintly and imperfectly indicated. Metathorax with a strong spine on each side. Hind ocelli about as far from one another as each from orbital margin.

Hab. - Las Cruces, N. M., close to the Agricultural College, Sept. II, I895, on Bigelovia wrightii. Recognized at once by its rufous abdomen and legs. The type is Ckll. 5or2.

\title{
IX. A Ceroplastes and its Parasite.
}

Ceroplastes euphorbiae, n. sp. $-q$ scale $3 \frac{1}{4} \mathrm{~mm}$. long, 3 broad, 23 high. Wax white, rather thick, firm, not divided into plates. The plate-nuclei or knobs, however, are very distinct, each on a small dark pink patch. Obscure bands of white secretion descend from the lateral ones. Denuded, the $q$ shows a well-formed caudal horn, about the shape of the last joint of one's little finger, but rather more tapering. The material being rather insufficient, the microscopic characters were not very well made out. The antennae appear to be only 6-jointed, but it is the fourth joint, not the third, that is much the longest. The second and third are next longest and subequal, the second perhaps a little the longer. The fifth is quite short. Derm with round glandpits. Legs ordinary, femur a little longer than tibia, tibia longer than tarsus. Digitules with large knobs. A detached leg exhibited a prodigiously long tarsal digitule, at least twice as long as the tarsus itself.

Half grown examples have the wax divided into plates, but the sutures are not darkened. Quite young ones are pink with all the knobs conspicuously white.

Hab.-Red Hill District, Jamaica, Oct. 28,1895 , on the twigs or branches of Euphorbia hypericifolia L., sent by Dr. M. Grabham.

This little species has some resemblance to $C$. iheringi Ckll., but will be known by its white wax, with the knobs on dark pink patches. From C. Aloridensis Comst., it will be known by its higher form, and the dark knobs of the adult, situated on dark pink patches. From $C$. euphorbiae I bred a parasite, which $\mathrm{Mr}$. L. O. Howard describes as a new genus and species of Aphelinine Chalcididae. His description follows.

T. D. A. Ckll.

Aneristus, n. gen.-Resembles Coccophagus. Flagellum of antenna strongly flattened. Scape short, inserted just above the mouth and reaching to the middle of the face; pedicel short, triangular, as long as broad. Funicle joint $I$ twice as long as pedicel, somewhat longer than broad. 
Funicle joints 2 and 3 each shorter than I, and 3 shorter than 2 ; each about as broad as is joint $I$ at tip. Club distinctly 3 -jointed, a little broader than funicle joint 3 ; joints $I$ and 2 of club subequal in length and each as long as funicle joint 3 . Joint 3 of club about as long as 2 , somewhat narrower at base than 2, pointed at tip. In other respects resembles Coccophagus, except that the hind tibiae are considerably flattened and have a row of short stiff bristles above. Middle tibial spur long and slender, nearly as long as first tarsal joint.
Aneristus ceroplastae, n. sp.-Female. Length, $.8 \mathrm{~mm}$.; expanse, $1.6 \mathrm{~mm}$.; greatest width of forewings, $.27 \mathrm{~mm}$. Mesonotum finely and closely shagreened, with sparse, rather long dark pile; eyes hairy; color black, slightly shining, all coxae and femora black; front and middle tibiae and all tarsi pallid, hind tibiae black. Wings with a very large discal infuscated patch, covering nearly half the wing area.

Described from 2 specimens reared by T. D. A. Cockerell from Ceroplastes on Euphorbia hypericifolia from Jamaica.

L. O. Howard.

\section{Preliminary Diagnoses of New Coccidae.}

\section{BY T. D. A. COCKERELL.}

The writer having lately prepared descriptions of various new Coccidae, which will appear in sundry bulletins, reports, proceedings of local societies, and so forth, it is deemed expedient to bring together some account of them here. This is done for the convenience of students, who sometimes complain of the difficulty of keeping track of scattered descriptions; and also to secure earlier publication, as some of the fuller accounts may be (indeed, have already been) much delayed. While the full details are not now given, there is sufficient descriptive matter, it is hoped, for the ready identification of the species. The species collected in Japan by $\mathrm{Mr}$. Takahashi were obtained for the Department of Agriculture and transmitted to me by Mr. L. O. Howard. Those collected by Prof. C. H. T. Townsend are also the property of the Department. Those obtained by Mr. Craw were collected at San Francisco in the course of his quarantine work. Full particulars concerning all of the Takahashi, Townsend and Craw species will be given in a forthcoming Bulletin of the Department of Agriculture. The West Indian forms will probably receive full publication in Trinidad.
Dactylopius olivaceus, n. sp. $-q$ long. $3 \frac{1}{2}$, lat. $2 \frac{1}{2}$, alt. I $\frac{1}{2} \mathrm{~mm}$. (in alcohol). Dark olivebrown, with mealy powder. Legs shorter than their distance from one another, very stout, coxa extremely large, digitules all filiform. Antennae brown, slender, 8-jointed, 8 very long. Formula 8 (123) (67) 54. Hairs of anal ring very small. Posterior tubercles obsolete. On Yucca, Ciudad Perfirio Diaz, Mexico (Townsend). Rather like D. glaucus, Maskell.

Eriococcus dubius, n. sp. $-q$ with sac a little over $3 \mathrm{~mm}$. long, sac loosely felted, white, with a slightly yellowish tinge. Dried \& very dark reddish-purple. Antennae 7-jointed, formula 34 (12) 756. Legs moderately slender, digitules ordinary. Posterior tubercles small but cylindrical. On some shrub, Valles, Mexico (Townsend). Very near to $E$. coccinens, Ckll., but apparently distinct.

Phenacoccus pergandei, n. sp. $-q$ with sac $8 \mathrm{~mm}$. long, 3 broad. Sac white, firm, partly overlapping the wrinkled orangebrown $q$. Antennae 9-jointed, formula 32 (14569) (78). Tarsus less than half as long as tibia. Digitules of claw of fair size, expanding rather gradually to their bulbous 

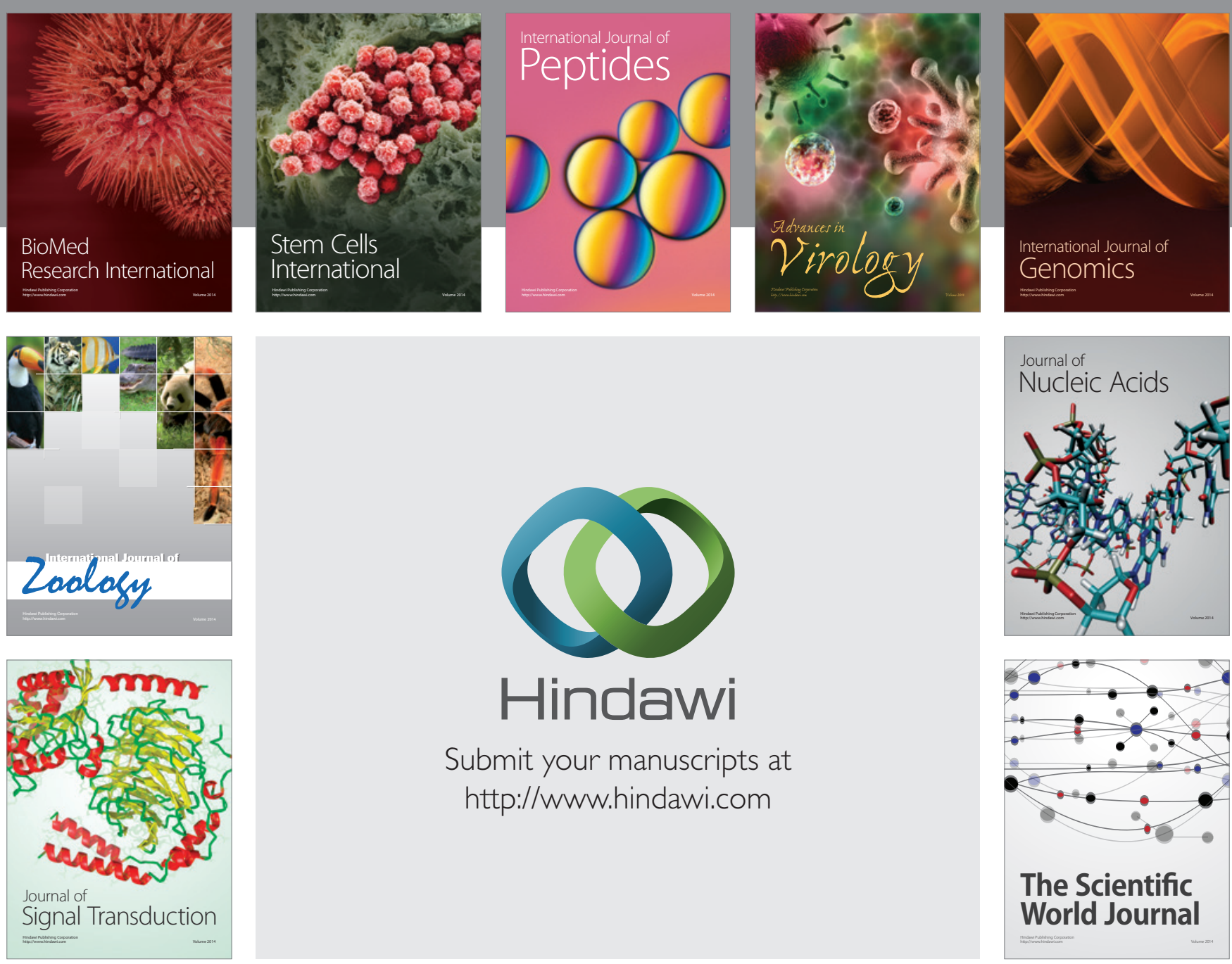

Submit your manuscripts at

http://www.hindawi.com
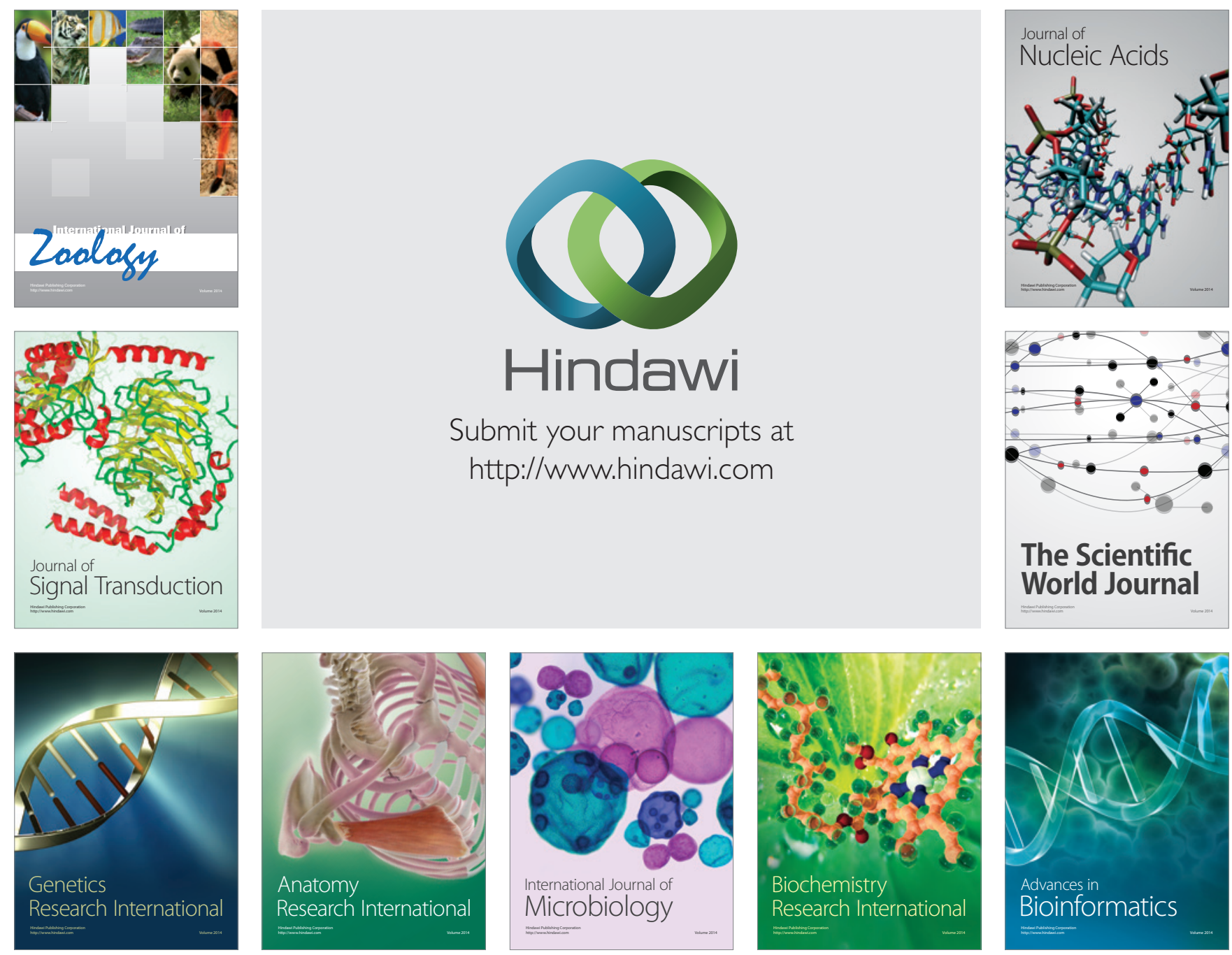

The Scientific World Journal
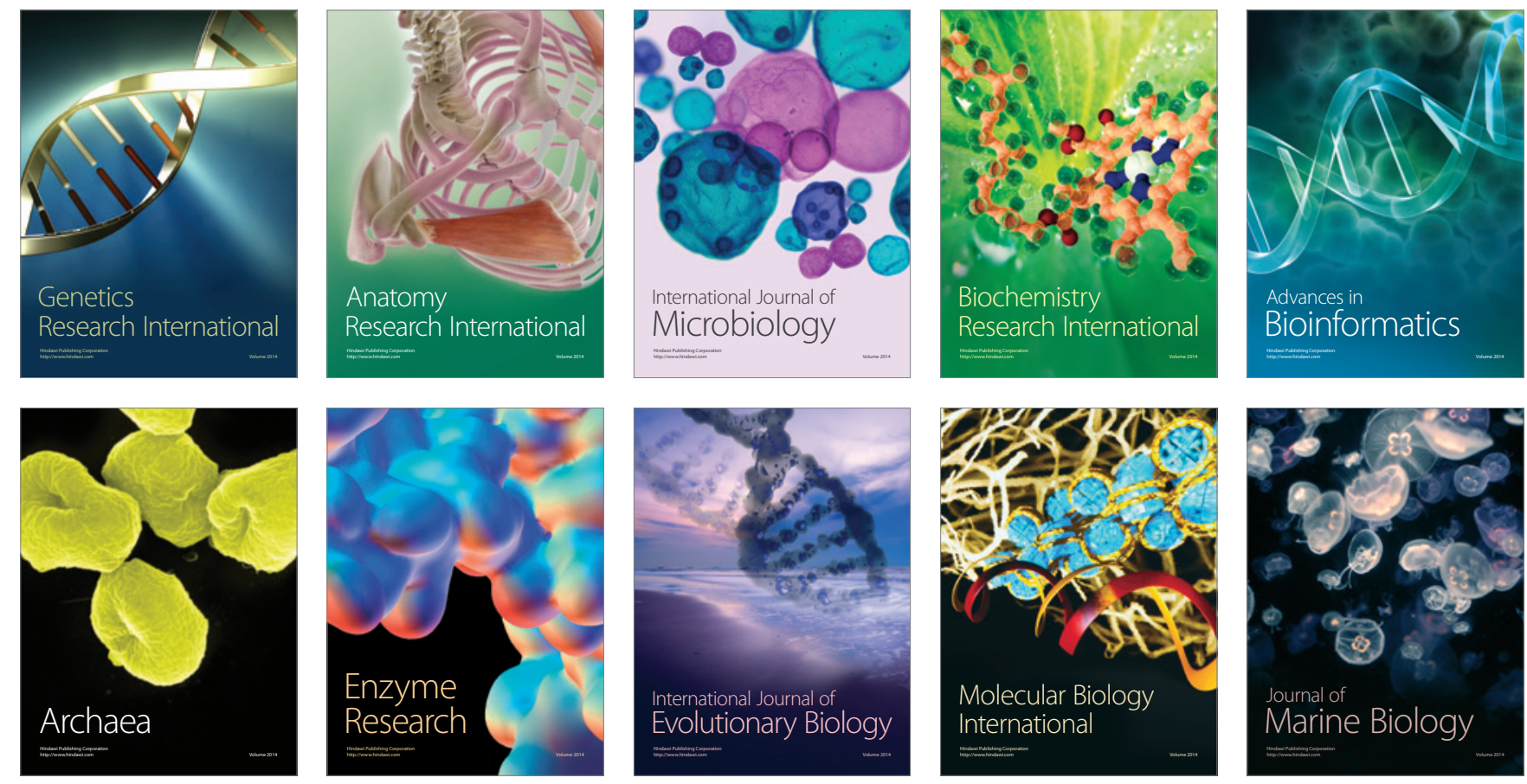